Acta Regionalia et Environmentalica 2

Nitra, Slovaca Universitas Agriculturae Nitriae, 2019, pp. 34-37

\title{
CALORIFIC VALUE OF BASIC FRACTIONS OF ABOVE-GROUND BIOMASS FOR SCOTS PINE
}

\author{
Rudolf PETRÁS ${ }^{1 *}$, Julian MECKO ${ }^{1}$, Ján KUKLA², Margita KUKLOVÁ ${ }^{2}$ \\ ${ }^{1}$ National Forest Centre, Forest Research Institute \\ ${ }^{2}$ Slovak Academy of Sciences, Institute of Forest Ecology
}

\begin{abstract}
In this work, the calorific value content in the dry matter of the Scots pine (Pinus sylvestris L.) trees was evaluated. This dry matter was obtained only from the above-ground fractions of its biomass. Our experimental material was taken from five Scots pine trees situated in Slovakia. Wood and bark samples were obtained from the discs which were cut off from three locations, namely from the stem, branches of tree crowns and needles. Then, calorific value capacity $\left(\mathrm{J} \mathrm{g} \mathrm{g}^{-1}\right)$ in the dry matter of each sample was determined. The impact of statistically significant factors on the calorific value capacity was determined by means of analysis of variance. The average values are, according to the fractions, approximately in the range of 20,000-22,200 J g $\mathrm{g}^{-1}$. The smallest capacity of the calorific value, approximately $20,000 \mathrm{~J} \mathrm{~g}^{-1}$, has the dry matter from bark obtained from the middle and crown parts of the stem. Then, the dry matter from stem wood and branches follows with a value of approximately $20,700 \mathrm{~J} \mathrm{~g} \mathrm{~g}^{-1}$. Then follows dry matter of the coarse bark occurring on the stem butt and twigs that are covered with needles with a value of about $21,900 \mathrm{~J} \mathrm{~g}^{-1}$; and finally pine needles with the highest values of about $22,200 \mathrm{~J} \mathrm{~g}^{-1}$. The calorific value variability is relatively low with coefficients of variations of $0.9-2.8 \%$.
\end{abstract}

Keywords: calorific value, pine, wood, bark, branches, needles

For the efficient energy use of tree biomass, it is necessary to know the calorific value content of not only whole trees but also of their parts. The primary process in biomass formation is photosynthetic assimilation, when organic substances are formed from inorganic ones and then solar energy accumulates in them. The amount of accumulated energy is very varying and depends on not only the amount, but also on the biomass structure that a particular tree produces for a fixed period of time. In forestry, biomass production is mostly expressed in volume units. The example here is presented in particular by the generally known tree volume tables, which indicate the biomass volume by the diameter and height of trees (Petráš and Pajtík, 1991). These tables are also found in the form of continuous mathematical models and simulate the biomass volume of not only whole trees (in $\mathrm{m}^{3}$ ), but especially also by their major parts such as volume of wood, bark and branches for instance. Such separation of tree biomass is usual mainly for the purposes of its industrial processing. For the energy use of biomass, it is necessary to know its energy equivalent. The easiest way for this expression is to recalculate the volume of biomass to its weight and, consequently, calorific value capacity. To do this, it is necessary to know not only the density of biomass ( $\mathrm{kg} \mathrm{m}-3$ ) by individual fractions, but also the calorific value $\left(\mathrm{J} \mathrm{g}^{-1}\right)$.

The knowledge of wood density are most commonly. They are reported for several tree species by Požgaj et al. (1997), but in particular Niemz and Sonderegger (2003). Matovič and Šlezingerová (1992) and Petráš et al. (2010,
2018) derived density values for bark and tree branches, too. Similar results are observed with the calorific value of individual biomass fractions. Pretzsch (2009) reports values of 20.36-20.79 $\mathrm{MJ} \mathrm{kg}^{-1}$ for spruce wood and 20.34-21.14 MJ kg ${ }^{-1}$ for branches and roots outside bark. Then, values for beech wood are 19.72-20.10 $\mathrm{MJ} \mathrm{kg}^{-1}$ and 20.78-23.13 MJ kg-1 for branches and roots outside bark. Klašnja and Kopitovič (1999) report the calorific value for willow wood at the level of $16.4-23.2 \mathrm{MJ} \mathrm{kg}^{-1}$ and for locust at the level of 21.9-24.2 $\mathrm{MJ} \mathrm{kg}^{-1}$. Calorific values of locust bark are lower by 1.5-5.5 $\mathrm{MJ} \mathrm{kg}^{-1}$. Oszlányi and Biskupský (1979) determined the calorific value for wood, bark and leaves of hornbeam, field maple, durmast oak and Turkey oak in the range of 18.12 to $20.65 \mathrm{~J} \mathrm{mg}^{-1}$. Petráš et al. (2013a) derived the average calorific values of wood for poplar clones at $18,430 \mathrm{~J} \mathrm{~g}^{-1}$, thin bark at $18,029 \mathrm{~J} \mathrm{~g}^{-1}$ and coarse bark at $17,38 \mathrm{~J} \mathrm{~g}^{-1}$. Larcher (2003) reports that tree species are richer in energy than herbaceous species, and in general, energy content depends directly on the carbon content in a substance. Of the plant substances, lignin with 26.4 , lipids with 38.9 and terpenes with up to $46.9 \mathrm{~kJ} \mathrm{~g}^{-1}$ have the highest energy content.

Based on the results of the domestic research into calorific value for poplar clones (Petráš et al., 2013a, 2013b; Jamnická et al., 2014), research with the same focus for other 11 economically important tree species continues at this time. The research starts with the density of basic fractions of the above-ground biomass of trees (Petráš et al., 2018a, 2019), then continues with their calorific value 
capacity (Petráš et al., 2018b) and ends with the production of calorific value of whole trees and stands.

The aim of this work is to investigate the calorific value content of above-ground biomass of scots pine trees (Pinus sylvestris L.) by their basic fractions (wood, bark, branches and needles).

\section{Material and methods}

The experimental material was obtained from five trees (Table 1), which were cut down in the areas of Zvolen (Stráž), the Little Carpathians (Smolenice), Záhorie (Gbely) and Spiš (Hranovnica). The selected trees are best characterized by their diameter in the range of $24-51 \mathrm{~cm}$, the height of 24-30 $\mathrm{m}$ and the age of 85-105 years. According to these values, we can conclude that they all have parameters of mature trees. They were cut in middle to high site index stands with an altitude of 165-850 m.

Three discs with bark were cut off from stems of each tree. The first disc was obtained from the foot of the stem; the second one from the middle part of the stem (approximately below the tree crown) and the third one from the crown part of stem. All three samples taken from stems were separated into wood and bark. For a more representative representation of the bark samples, a larger amount of bark had to be peeled from that part of the stem, where discs were cut off. Other samples were taken from tree crowns. The fourth sample was obtained from the branches outside bark; the fifth one from twigs, which are usually covered with needles and the sixth one represents needles only. Nine samples were available for each tree in total. Three samples from stems were intended for wood, three for bark and one sample separately for branches outside bark, twigs and needles. The total of 45 samples was taken from all five trees in total.

Large stem discs were cut radially to smaller triangular parts before drying so that the direct proportion of sapwood and core wood was preserved. All samples were dried at $103 \pm 2{ }^{\circ} \mathrm{C}$ and then pulverised. The weight of dried samples was approximately 180-750 g. Needles and twigs samples were the smallest samples and wood samples were the largest samples. The calorific value of samples was determined by means of an IKA C-4000 calorimeter (program C-402, standard DIN 51900). Two determinations were obtained from each sample and then average values $\left(\mathrm{J} \mathrm{g}^{-1}\right)$ from these determinations were calculated. The variability was examined and the most important factors on which the calorific value capacity depends were determined. A single factor analysis of variance (ANOVA) was used for that purpose by using the computer program QC.Expert (Kupka, 2013). ANOVA proceeds from the principle of addition of variances of known reasons (factors) $\sigma_{i}^{2}$ and unknown (random) $\sigma_{\text {residual }}^{2}$ to total variance $\sigma_{\text {total }}^{2}$ :

$$
\sigma_{\text {total }}^{2}=\sum \sigma_{i}^{2}+\sigma_{\text {residual }}^{2}
$$

In the analysis of variance, only one factor (biomass fraction) was considered as a reason with nine levels (wood and bark in three locations of stem, then branches outside bark, twigs and needles).

\section{Results and discussion}

From the results of single factor analysis of variance we can conclude that the effect of the biomass fraction on the calorific value content is statistically significant. The calculated $p$-value of $4.92 \mathrm{E}-12$ is smaller than the given significance level $(p=0.05)$. The bark in the middle and crown parts of the stem (Figure 1) has the lowest calorific values, approximately $20,000 \mathrm{~J} \mathrm{~g}^{-1}$. Three fractions, namely twigs, bark from the stem foot and needles, have highest values of about $21,900-22,200 \mathrm{~J} \mathrm{~g}^{-1}$. The variability of these fractions is relatively low with a coefficient of variation of $0.9-3.3 \%$. Subsequently, the differences between the pairs of averages of all nine fractions were tested by the Scheffe method. Differences among three fractions with the highest-values (Twigs, B1 and Needles) were statistically insignificant and the differences among other six fractions with the lowest values were also statistically insignificant. Based on this result, the fractions among which there were no significant differences were merged together. The actual content of the fraction was also taken into account when merging. Six sets were first created (Fig. 2) from nine sets, and later five larger sets. This resulted in a separate fraction for wood and branches outside bark, for bark in the middle and crown part of stem, for twigs, for bark from the foot of stem and for needles (Fig. 3). Average values remained in the range of approximately $20,000-22,200 \mathrm{~J} \mathrm{~g}^{-1}$, but their variability decreased slightly to $0.9-2.8 \%$.

According to preliminary results (Petráš et al., 2018), other economically important tree species also have a similar but slightly lower calorific value content. Spruce and fir needles are in the range of about 20,000 to $21,600 \mathrm{~J} \mathrm{~g}^{-1}$, which is $90-97 \%$ of the pine level. Other fractions have $20,000-20,300 \mathrm{~J} \mathrm{~g}^{-1}$, which is $97 \%$ of the pine level. The deciduous tree species such as oak, beech and hornbeam have a calorific value of wood and branches in the range

Table $1 \quad$ Basic characteristics of cut trees and stands

\begin{tabular}{|c|c|c|c|c|c|c|}
\hline Tree number & Diameter $\left.\mathbf{d}_{\mathbf{1 . 3}} \mathbf{( c m}\right)$ & Height $\boldsymbol{h}(\mathbf{m})$ & Age & Site index & Altitude (m) & Area (locality) \\
\hline \hline 14 & 24 & 25 & 105 & 30 & 350 & Zvolen \\
\hline 27 & 26 & 27 & 90 & 30 & 275 & Smolenice \\
\hline 29 & 35 & 24 & 88 & 26 & 165 & Gbely \\
\hline 33 & 36 & 26 & 85 & 26 & 165 & Gbely \\
\hline 75 & 51 & 30 & 101 & 24 & 850 & Hranovnica \\
\hline
\end{tabular}




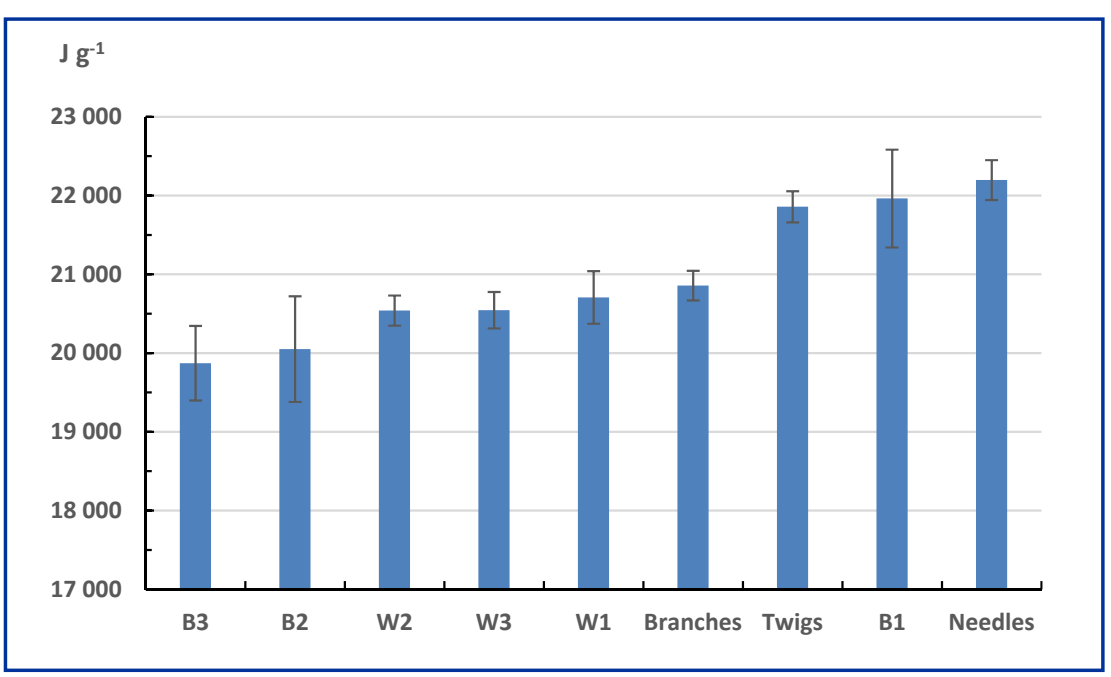

Figure 1 Calorific value capacity by basic fractions

B - bark, W - wood, by its location within the stem: 1 - the foot, 2 - the stem middle, 3 - in the stem crown

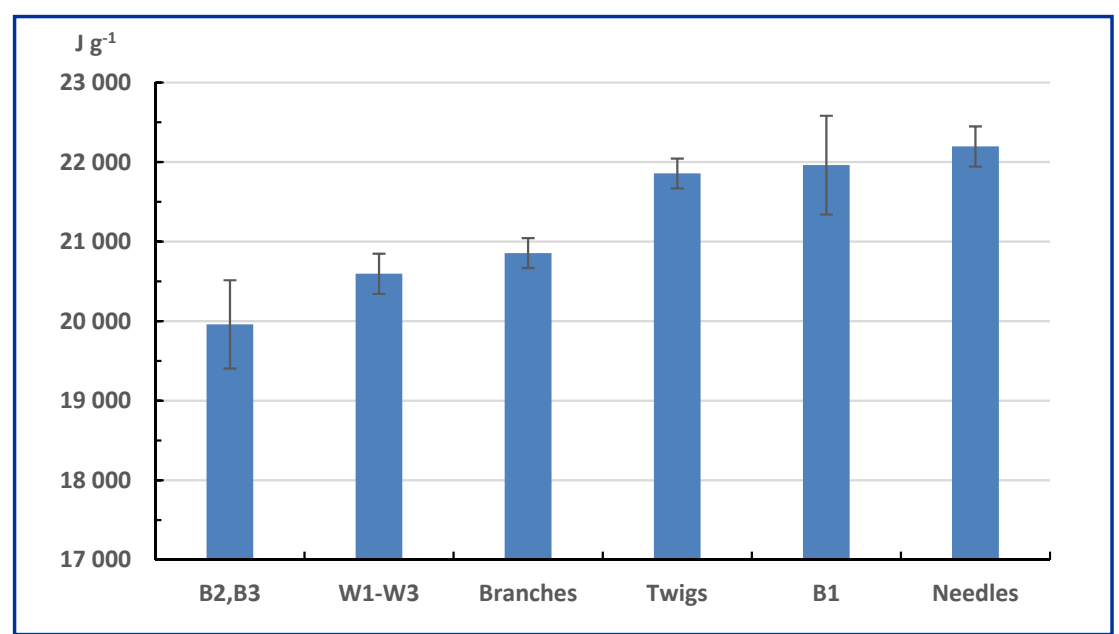

Figure 2 Calorific value capacity by merged fractions

B - bark, W - wood, by its location within the stem: 1 - the foot, 2 - the stem middle, 3 - in the stem crown

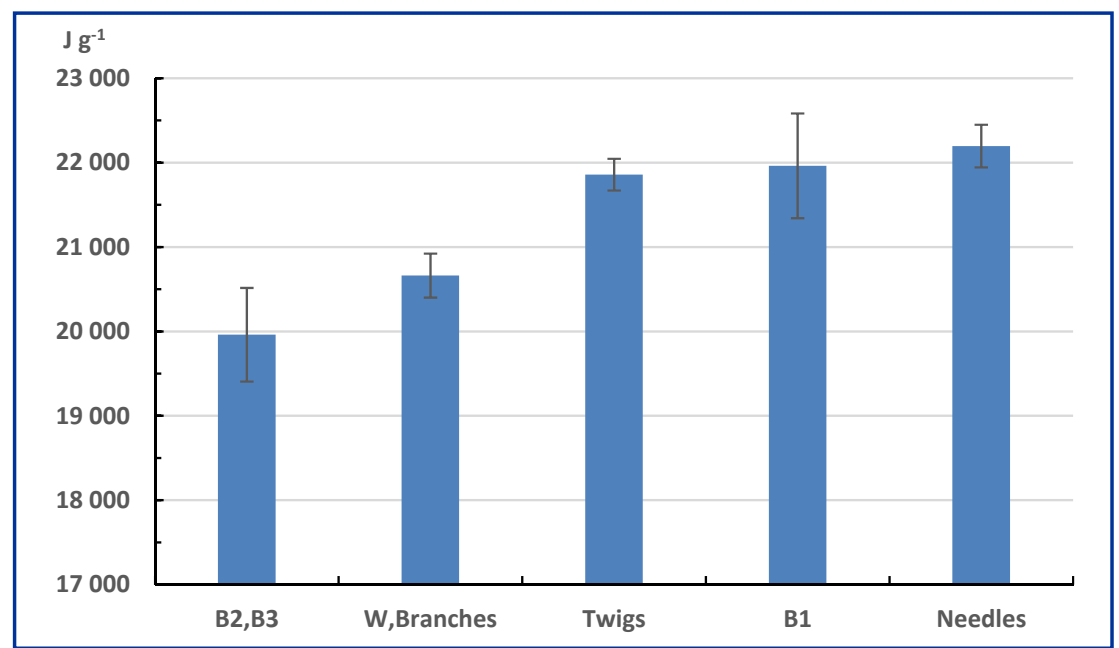

Figure 3 Resulting calorific value capacity for merged fractions B2,3 - bark in the middle and crown part of the stem, W - wood of the whole stem, K1 - bark from the stem foot of $19,200-19,800 \mathrm{~J} \mathrm{~g}^{-1}$, but the bark achieves only $17,700-18,700 \mathrm{~J} \mathrm{~g}^{-1}$. In proportion to pine, it is $98 \%$ for wood and $90 \%$ for bark. Hardwoods have lower calorific value content even though they have higher density of wood than coniferous species. Accordingly, we can conclude that the calorific value content of biomass is not increasing only due to its higher density, but also because of the content of other non-wood substances such as e.g. lipids or terpenes. Pine biomass has the most of these substances compared to other wood species.

\section{Conclusions}

The calorific value content was determined in the dry matter of the above-ground biomass of scots pine. Experimental material was obtained from five trees growing in the forests of Slovakia. Nine samples of biomass matter were taken from each tree. These samples consisted of separate wood and bark samples from the lower, middle and top parts of stems. Then, samples of branches outside bark and twigs covered with needles were taken from the tree crowns. In the laboratory, these were manually separated into needles and twigs. All samples were then dried at $103 \pm 2{ }^{\circ} \mathrm{C}$ and pulverised. Calorific value capacity for each fraction was then determined $\left(\mathrm{J} \mathrm{g}^{-1}\right)$. The analysis of variance examined the effect of statistically significant factors on the calorific value capacity. The results showed that the average values of above-ground biomass of scots pine are in the range of $20,000-22,200 \mathrm{~J} \mathrm{~g}^{-1}$ by their specific biomass fraction. The lowest calorific value capacity, approximately $20,000 \mathrm{~J} \mathrm{~g} \mathrm{~g}^{-1}$, has dry matter of the thinner bark in the middle and crown part of stem. This is followed by the dry matter of stem wood and branches with its value of approximately $20,700 \mathrm{~J} \mathrm{~g} \mathrm{~g}^{-1}$, then by dry matter of coarse bark from the foot of stems, and twigs that are covered with needles follow with a value of nearly $22,000 \mathrm{~J} \mathrm{~g}^{-1}$, and the highest calorific values, approximately $22,200 \mathrm{~J} \mathrm{~g}^{-1}$, have pine needles. The calorific value variability is relatively low with its coefficients of variation of $0.9-2.8 \%$. The calorific value content of the pine biomass is higher compared 
to other tree species mainly due to higher resin content in all fractions.

\section{Acknowledgements}

This work was supported by the Slovak Research and Development Agency under the contract No. APVV-16-0344.

\section{References}

JAMNICKÁ, G. - PETRÁŠOVÁ, V. - PETRÁŠ, R. - MECKO, J. - OSZLÁNYI, J. 2014. Energy production of poplar clones and their energy use efficiency. In iForest, 2014, no. 14, pp. 150-155.

KLAŠNJA, B. - KOPITOVIČ, Š. 1999. Quality of wood of some willow and robinia clones as fuelwood. In Drevársky výskum, 1999, no. 44, pp. 9-18.

KUPKA K. 2013. QC.Expert 3.1. In Uživatelský manuál, Pardubice : TryloByte, Ltd., 2013, 266 pp.

LARCHER, W. 2003. Physiological Plant Ecology: Ecophysiology and Stress Physiology of functional groups. $4^{\text {th }}$ ed., New York : Springer, 2003, 513 pp.

MATOVIČ, A. - ŠLEZINGEROVÁ, J. 1992. Konvenční hustota dřeva větví smrku obecného (Picea abies Karst.). In Zborník medzinárodnej vedeckej konferencie Les, drevo, ekológia, Sekcia 4. Štruktúra a vlastnosti dreva v technologickom využití, 1992, pp. 53-59.

NIEMZ, P. - SONDEREGGER, W. 2003. Untersuchungen zur Korrelation ausgewählter Holzeigenschaften untereinander und mit der Rohdichte unter Verwendung von 103 Holzarten. In Schweizerische Zeitschrift für Forstwesen, 2003, no. 154, pp. 489-493.

OSZLÁNYI, J. - BISKUPSKÝ, V. 1979. Energetická hodnota nadzemnej biomasy drevín v dubovo-hrabovom lese. In Acta Ecologica, 1979, no. 20, pp. 59-105.
PETRÁŠ, R. - PAJTíK, J. 1991. Sústava česko-slovenských objemových tabuliek drevín. In Lesnícky časopis, 1991, no. 37, pp. 49-56.

PETRÁŠ, R. - MECKO, J. - NEUSCHLOVÁ, E. 2010. Density of basic components of above-ground biomass of poplar clones. In Wood Research, 2010, no. 55, pp. 113-122.

PETRÁŠ, R. - MECKO, J. - OSZLÁNYI, J. - PETRÁŠOVÁ, V. - JAMNICKÁ, G. 2013a. Landscape of danube inland-delta and its potential of poplar bioenergy production. In Biomass And Bioenergy, 2013, no. 55, pp. 68-72.

PETRÁŠ, R. - MECKO, J. - PETRÁŠOVÁ, V. 2013b. Energy potential in production of fast-growing poplar clones in slovak regions. In Acta Regionalia et Environmentalica, 2013, no. 10, p. 53-56.

PETRÁŠ, R. - MECKO, J. - KRUPOVÁ, D. - SLAMKA, M. 2018a. Predbežné výsledky výskumu hustoty nadzemnej dendromasy hospodársky významných druhov drevín. In Baláš, M. - Podrázský, V. - Gallo, J. (eds.): Proceedings of Central European Silviculture. Praha: ČZU, 2018, no. 8, pp. 94-101.

PETRÁŠ, R. - MECKO, J. - KUKLOVÁ, M. - KUKLA, J. 2018b. Výskum kapacity spalného tepla lesných drevín. In Gálik, B. - Zelinková, G. (eds.): Recenzovaný zborník vedeckých prác Slovenskej spoločnosti pre polnohospodárske, lesnícke, potravinárske a veterinárske vedy pri Slovenskej akadémii vied, pobočka Nitra. Nitra : SPU, 2018, pp. 277-284.

PETRÁŠ, R. - MECKO, J. - KRUPOVÁ, D. - SLAMKA, M. 2019. Aboveground biomass basic density of softwoods tree species. In Wood Research, 2019, no. 64 (in print).

POŽGAJ, A. - CHOVANEC, D. - KURJATKO, S. - BABIAK, M. 1997. Štruktúra a vlastnosti dreva. Bratislava : Príroda, 1997, 485 pp.

PRETZSCH, H. 2009. Forest Dynamics, Growth and Yield. Berlin : Heidelberg, Springer, 2009, $664 \mathrm{pp}$. 